This item was submitted to Loughborough's Research Repository by the author.

Items in Figshare are protected by copyright, with all rights reserved, unless otherwise indicated.

\title{
Research literacy: contextual affordances and the ongoing quest for sustainability and research quality
}

PLEASE CITE THE PUBLISHED VERSION

http://dx.doi.org/10.1080/02671522.2017.1322354

\section{PUBLISHER}

(c) Taylor \& Francis

\section{VERSION}

AM (Accepted Manuscript)

\section{PUBLISHER STATEMENT}

This work is made available according to the conditions of the Creative Commons Attribution-NonCommercialNoDerivatives 4.0 International (CC BY-NC-ND 4.0) licence. Full details of this licence are available at: https://creativecommons.org/licenses/by-nc-nd/4.0/

\section{LICENCE}

CC BY-NC-ND 4.0

\section{REPOSITORY RECORD}

Waring, Michael. 2019. "Research Literacy: Contextual Affordances and the Ongoing Quest for Sustainability and Research Quality". figshare. https://hdl.handle.net/2134/25727. 


\section{COMMENTARY}

\section{Research literacy: contextual affordances and the ongoing quest for sustainability and research quality}

\section{Michael Waring}

School of Sport, Exercise and Health Sciences, Loughborough University, Loughborough, UK

\section{m.j.waring@lboro.ac.uk}

Contextually, there are immediate similarities and variations evident between the ECTs

(Hayes; Kerr; Nation-Grainger). The similarities are that all of the ECTs had been part of the same initial teacher education programme at the same university; were part of the same NQT and Beyond, and Masters programme at the same university; were in full-time employment as teachers; had an established and positive collaborative relationship with a university and each other which was framed around an explicit research-informed pedagogical framework (PLSP); were engaged in conducting a project which focused on critically reflecting on their practice in school; and committed to trying to engage with the research literature and research process to enhance their practice and the quality of pupils' experiences in school.

Variations between the ECTs were the age of pupils they taught; the subjects they taught; the roles and responsibilities which they had in their workplace; and paradigmatical locations. Inherently framed within this background is each ECT's personal drive and desire to develop pupils' experiences and themselves in order to support pupils' learning, as well as the 'mechanics' of a collaborative and progressive programme which 'automatically' promotes/generates opportunities and evidence of the effective integration of research into practice. However, the nature and extent of the 'ownership'/'internalisation' of the 'research process' and its associated principles, knowledge, skills, and understanding is a vitally 
important dimension influencing whether the research is to be effectively integrated, and of increasing quality as part of sustained practice.

This brief review of the three papers is specifically focused on ECTs' ownership and integration of the 'research process' as part of a legitimate and sustainable process of integrating research into professional practice.

All of the ECTs followed a similar structure for the presentation of their papers, and offered logical considerations and research-informed decisions aligned with the research process, presenting appropriate conclusions and recommendations based on their analysis of data and discussion as part of conducting a research project in their workplace.

Consequently, all papers on one level presented evidence of integration of research into their practice.

However, differences are evident in the ways in which the ECTs distinguish themselves in terms of the level of integration of the 'research process' within their workplace. The most striking element associated with this is how their roles and responsibilities were used to frame 'the problem' and nature of the subsequent integration of the research process beyond themselves in the workplace and explicitly involving colleagues across the school. This seems to be part of taking ownership of things which will be used to judge them, for example, any formal responsibilities for the quality of teaching and learning they have beyond their own class teaching.

The recommendations made in each paper were relevant to their findings and had potential to enhance the quality of pupils' learning experiences and inform the development of teaching 
practices. However, the extent to which they acknowledged the implications and took ownership of and focus on ongoing research-informed practice beyond this study as part of achieving their transformational potential varied. This was again fundamentally a consequence of the roles they had.

Other key elements that identify themselves in support of ECT research literacy included confidence to: address the demands of their role; confront professional concerns; identify and generate research evidence in support of their role, manage concerns; and suggest and promote developments to enhance the quality of teaching and learning in their school and beyond. For example, confidence as part of the process of research and justification of what they had done and the specific and tangible evidence which they had in relation to their particular context, and supported by broader research evidence/literature. But also confidence in their learning and development, to be comfortable with listening, supporting learner autonomy, and facilitating student voice, as they uncover/address pupils' and their own beliefs, critical conversations and reflection, and the tools and framework to develop further.

Another dimension which the papers show only as a consequence of their publication is the resilience which all three authors have shown as part of a process of reiteration and critical reflection and which extends beyond the considerable demands of the research literacy which they have demonstrated.

Finally, the importance of quality in teaching and learning, and in research, is something that needs to be continually developed theoretically as well as experientially as part of collaboration with universities, schools, colleagues within, and beyond their workplace (BERA/RSA, 2015; Brown, Rowley, and Smith, 2016). The need to maintain an 'external 
eye' to be cognisant and reflective, being able to maintain a critical stance is vital as part of research literacy (Winch, Oancea and Orchard, 2015).

\section{References}

BERA/RSA. 2015. The Role of Research in Teacher Education: Reviewing the Evidence.

Final report of BERA-RSA inquiry. BERA/RSA.

Brown, T., H. Rowley, and K. Smith. 2016. The Beginnings of School Led Teacher Training:

New Challenges for University Teacher Education. School Direct Research Project Final

Report.

Manchester: Manchester Metropolitan University.

Winch, C., A. Oancea. and J. Orchard. 2015. "The Contribution of Educational Research to Teachers' Professional Learning: Philosophical Understandings.” Oxford Review of Education 41 (2):145-153.

http://www.tandfonline.com/doi/abs/10.1080/03054985.2015.1017406,

http://www.tandfonline.com/toc/core20/41/2. 